\title{
Toleration, Tolerance, or Intolerance in the Works of the Young Martin Luther
}

\section{The Issue with Jews in Early Sixteenth-Century Christian World View}

\author{
Albrecht Classen ${ }^{1}$ \\ ${ }^{1}$ The University of Arizona, United States \\ Correspondence: Albrecht Classen, The University of Arizona, United States. E-mail: aclassen@email.arizona.edu
}

Received: April 11, 2018; Accepted: April 23, 2018; Published: May 3, 2018

\begin{abstract}
Martin Luther's hateful and anti-Judaic sentiments have attracted much attention especially because they have often been identified as highly influential on modern anti-Semitism. But in his early years, Luther could harbor quite different attitudes. A critical reading of his treatise Daß Jesus Christus ein geborner Jude sei from 1523 will allow us to gain important insights into the delicate and yet impactful approach to toleration as it had developed throughout the Middle Ages. While Luther espoused a specific form of toleration, he cannot be identified as a defender of tolerance in the modern sense of the word. Tragically, however, despite his early attempt at reaching out to people of Jewish faith, the famous reformer quickly changed his mind and embraced a most aggressive strategy against Jews at large. This article will highlight the intricate and fragile nature of toleration as it was pursued by many medieval and early modern intellectuals and writers, and demonstrate that this ideal was highly appealing, but also subject to quick changes to the opposite.
\end{abstract}

Keywords: Martin Luther, Jews, anti-Judaism, tolerance, intolerance, toleration, Protestant Reformation, paradigm shift

\section{Introduction}

Hardly any other topic has attracted so much attention from Luther and Reformation scholars as the question whether he harbored a tolerant or an intolerant attitude toward non-Christians. In particular, the issue focuses on Luther's relationship with Jews, a very problematic and often rather painful topic that has both historical and modern relevance. After all, the Protestant Reformation is often popularly associated with the beginning of modernity, with the rise of rationality, and with freedom, at least from the Catholic Church. Enlightenment and the triumph of the human intellect are commonly said to be based on the revolutionary contributions by Luther and his companions. Indeed, there is universal consensus that the Reformation represented an enormous watershed in the sixteenth century, bringing about the establishment of a new reformed Church, which in turn forced the Catholic Church to retreat, retrench, reinvigorate itself, and subsequently to endeavor its Counter-Reformation, relying heavily on the newly founded Jesuit Order (1540). On the Protestant side, clerical celibacy was finally lifted, and the individual was strongly encouraged to search for God himself, at least according to the new principles of sola fides and sola gratia.

However we would view the Reformation era today, it was certainly a time of a major paradigm shift leading us away from the Middle Ages and into modernity. (Note 1) Nevertheless, we have to be very careful in our modern assessment of Luther as the figurehead for an assumed wave of secularization, individual freedom, and desacralization since the early sixteenth century. (Note 2) We can hardly claim the Protestant Reformation as the basis for the rise of the modern, rationally determined state, for instance, as Matthias Pohlig now argues convincingly. (Note 3)

\section{Method}

This study is primarily concerned with a major paradigm shift in Martin Luther's thinking and attitude about nonChristians, especially Jews. The majority of Luther scholars have focused on his later writings in which he developed increasingly negative, even hostile perspectives regarding Jews whom he then wanted to be eliminated, almost in a precursor to the Holocaust in the twentieth century. (Note 8) But we should not ignore the fact that in his early years he was fully capable and willing to acknowledge Jews as valid contemporaries and worthy co- 
religionists. In fact, we could call Luther's intellectual approach to this larger issue as 'toleration,' though certainly not 'tolerance,' as I will outline below.

\section{Current Research}

In previous years we also assumed that Luther and his fellow reformers succeeded in liberating women from their traditional constraints, granting them freedom from the world of convents, allowing nuns to marry and to have children. However, the dissolution of monasteries mostly meant that women had hardly any alternative left but to marry and to submit under a patriarchal husband, whereas their traditional access to intellectual education, which commonly took place in convents, was suddenly cut off. (Note 4) There are many other issues in daily life and in the history of mentality that were deeply affected by the Reformation, though it has become exceedingly clear in recent years that we have to be rather skeptical regarding the traditional optimism and idealization of the movement launched by Luther. History is not necessarily progressive, as much as the modern generation likes to view itself compared to the past. (Note 5) This also applies to the history of the Protestant Church, which quickly developed into a highly orthodox, hierarchical organization with very little interest in tolerating any minorities, heretics, or deviants. (Note 6)

Nevertheless, on October 31, 2017, during a church service in St. Lawrence in Nuremberg, celebrating the quincentenary of Luther's nailing of the ninety-five theses on the door of the castle church of Wittenberg, Heinrich Bedford-Strohm, chairman of the EKD, a German umbrella organization of Protestant, Lutheran and reformist churches, while praising Luther's actions as liberating in many ways, also warned: "Reformation 2017 - das heißt auch, den alten unseligen christlichen Antijudaismus hinter uns zu lassen, der den tödlichen antisemitischen Rassenlehren Nahrung gegeben und so viel Leid angerichtet hat" (Reformation 2017 - that also means to leave behind the old unholy Christian Antijudaism, which provided food for the deadly anti-Semitic race theories and caused so much suffering). (Note 7) In an article published in the Frankfurter Allgemeine Zeitung on Nov. 23, 2017, Salomon Korn, famous architect and President of the Jewish Community in Frankfurt a. M., voiced his great concern about the seeds which Luther's anti-Jewish comments planted and which contributed to the rise of modernanti-Semitism, the Nazi ideology, and subsequently the Holocaust. Not by accident did Luther's treatises directed against the Jews experience a tremendous revival during the 1930s, and Korn is correctly warning against the "Funkenschlag des Antisemitismus" (incendiary power of anti-Semitisim) which could easily challenge the basic democratic principles of the western world. (Note 8)

Historians, scholars of religion, art historians, and others have systematically and thoroughly plowed through Luther's life and works, and it almost seems as if no stone has been left unturned in our efforts today to understand what really happened at that crucial moment five hundred years ago. In 2017 alone, many monographs appeared dedicated to this outstanding figure and his contributions to the global transformation of the traditional Catholic Church and hence to early modern society. (Note 9) As to be expected, many aspects pertaining to Luther's teachings have been viewed rather controversially, and hardly any other has been discussed, as we have seen already, so acrimoniously as his attitude toward Jews. (Note 10) We might go so far as to identify the individual positions vis-à-vis Jews as a litmus test for all early modern intellectuals, determining whether they pursued a hostile or a peaceful attitude, and whether they approached the essential social tasks of their time in an inclusive or exclusive fashion. (Note 11) Was the new Protestant Church tolerant, and would this term even make sense in its historical context?

The purpose of this paper cannot be to open this old Pandora's Box again and either rally to Luther's defense by pointing out maybe positive comments he might have made about Jews, or to lean heavily on some of his later texts where he increasingly turned hateful against Jews and undoubtedly transformed into an anti-Judaist, as Peter von der Osten Sacken alerted us already in 2003. (Note 12) Considering the flood of pamphlets, broadsheets, plays, poems, and other media where strongly anti-Judaist concepts found an outlet during the sixteenth century, it would not come as a surprise to recognize in Luther a full member of this movement, maybe even one of its most outspoken representatives, giving much legitimacy to those hateful ideas about the Jewish population in Germany. (Note 13) This would definitely be true in light of his later publications, which scholarship has scoured already at great length, often in an explicit attempt to 'demystify' this great personality and to expose him in his more aggressive and hostile character, especially vis-à-vis Jews. (Note 14)

Most great writers, thinkers, philosophers, and other intellectuals throughout time have undergone significant changes in his/her worldview, concepts, understandings, attitudes, opinions, and conclusions. Those changes have been at times rather subtle, but at other times also rather radical, which forces us to make a decision at some point which one approach pursued by the individual under investigation deserves more or less of our attention. We could also, which will be the emphasis of this paper, distance specific texts from the author and accept them as part of a 
larger discourse at a specific moment in time, irrespective of the writer's later positions regarding special issues. This would allow us to decouple the philosophical and philological investigation from the biographical perspective and grant us more objectivity on a narrative-analytic level.

Virtually every text has been composed within a specific traditional framework from which it emerged either in approval or in rejection of the majority viewpoint. Consequently, it proves to be rather helpful to focus on the individual text and recognize it as part of a larger chain, instead of evaluating it both in light of the author's outlook in his/her younger and older years. It would be useless, for instance, to try to draw connections between the ideas formulated by a young writer with those formulated at his old age. For instance, Goethe's Die Leiden des Jungen Werthers has to be evaluated independently from his much later Faust, even if there might be interesting correlations. This applies to Luther as well; hence I will subsequently turn the attention to a famous early treatise by him regarding Jews: Daß Jesus Christus ein geborner Jude sei (1523), (Note 15) but leave aside the most hateful writings of his later period, such as his Wider die Sabbater (1538), Ein Sendbrief Rabbi Samuelis (1538), Von den Juden und ihren Lügen (1543), Von den letzten Worten Davids (1543), Vom Schem Hamphoras und vom Geschlecht Christi (1543), and Eine Vermahnung wider die Juden (1546). (Note 16)

Already in 1911, in his doctoral dissertation, Reinhold Lewin had outlined the three phases of Luther's relationship with Jews, divided into the early phase of mostly detached ignorance, the middle phase being determined by Luther's hope that all Jews would convert to Christianity, and the last phase being a time of bitter disappointment and growing hostility. Lewin received considerable support for his assessment, but he was also criticized for his presumed overly 'psychologizing= approach which would egregiously leave out theological concepts. Yet, the global division between the early and the late Luther can certainly be upheld until today, despite many attempts at discriminating the entire issue further by modern scholarship. (Note 17)

Before we proceed, however, it would be necessary to clarify our terms a little, without going into a lengthy debate because tolerance itself constitutes a highly complex topic. Toleration indicates that the individual holds steadfastly to his own religion, ideology, or conviction, but does not severely object to other positions, even if s/he disapproves of them. Tolerance, by contrast, takes one big step forward and makes the own position available as something debatable because other perspectives are recognized as possible and worthy as well, as long as the opposing side does not intend to destroy the one who pursues tolerance. Toleration maintains a marked distance, but does not reject the other; tolerance includes the other as an enrichment of the own world and invites the other to debate the issues as they arise in a friendly and constructive manner. As Gotthold Ephraim Lessing's famous play Nathan the Wise (1779), with its ring parable addressing the issue of the three world religions in competition with each other, already indicated, there are many ways of searching for God and to practice different rituals and customs in that process. God, however, loves them all and happily embraces every religion because they all pursue the same goal, the worship of the divine, and this irrespective of their differing religious rituals and formal criteria. (Note 18)

The individual is called upon to approach the other and to acknowledge that we are all members of the same universal family. Toleration, by contrast, as we can find it quite commonly already in the Middle Ages and beyond, still perceives clear borders between the religions and identifies Christianity, for instance, as the only true religion, even though the presence of other believers cannot be denied. Those who embrace toleration sympathetically acknowledge the very noticeable differences among people, but they do not take serious measures in dealing with representatives of other cultures and in possibly trying to incorporate them. (Note 19)

As I will outline below, we encounter in the young Martin Luther a man who was well attuned to the intellectual and theological debates in the fifteenth and sixteenth centuries and was personally searching hard for ways how to reach out to those who held different beliefs and to bring them into his own fold, that is, especially, Jews, whom he wanted to convert to the natural family of the true faithful. The very essence of Luther's teachings, and this would be a highly consistent element in all of his thinking, found its most famous and insightful expression in the phrase sola fide. In the face of God, as Heiko A. Oberman noted, the human creature would have to defend and justify itself, irrespective of his/her religion here on earth. This apocalyptic perspective reduced the formal differences between, say Christians and Jews, and demanded a direct confrontation of the individual with God.(Note 20) The young Luther actually viewed the Jews as important partners in a religious dialogue which the Christians would have to win in order to find their own true position. (Note 21)

Undoubtedly, the Jews' position in Germany during the early sixteenth century was dire and dangerous, complicated and precarious, but they were not entirely outcast and found a variety of ways of living within the Christian society which defies many of our modern assumptions concerning their Ghettoization, expulsion, and the numerous pogroms. (Note 22) The very hostility displayed by the late Luther actually indicates how much 
Jewish life was still very present at that time and that Jews and Christians enjoyed fairly close contacts on many different levels. Many historical, literary, social-political, and religious documents from the entire sixteenth century confirm that Luther's railing against the Jewish community during his old age did not amount to much, as vitriolic as his comments proved to be. (Note 23) Intriguingly, in his young days he harbored very different perspectives, but then he became hardened increasingly in the course of time.

Although Luther's tract Daß Jesus Christus ein geborner Jude sei has been discussed many times before, it deserves a much closer analysis in order to identify the specific character of the author's sense of toleration. (Note 24) Following, I will offer a close reading of the text, mirroring the relevant scholarship indirectly, whereas the writer's comments will stand in the foreground. In the process of our analysis I will try to apply the different definitions of toleration vs. tolerance in order to establish a more objective perspective on Luther's writing.

After having rejected all kinds of accusations against himself, obviously raised by his Catholic opponents who tried to categorize him as a heretic and who seemed to harbor a variety of strange ideas about Mary, the Mother of God, and her virginity, for instance, Luther turns to more serious matters and begins with his reflections on the observation that Christ originated from a Jewish family. This, in turn, motivates him to ponder on the possibility of converting some Jews to the Christian faith (314). As is very common in his strategic approach, he bitterly complains about the Catholic clergy that has treated the Jews in such a mean-spirited way that any good Christian might have rather considered converting to Judaism to escape from such evil authority figures (314). In fact, he imagines that if he had been a Jew and had witnessed the terrible performance by the Christian authorities and teachers, he himself would have rather turned into a pig than into a Christian (315). Essentially, Luther uses the Jews to strengthen his own stance against the Catholic Church, arguing that its representatives have treated the Jews like dogs, but not like people (315). In the case of a conversion to Christianity, the Church authorities entirely neglected to demonstrate true Christian values, behavior, and understanding. In any theological debate, Jews would have realized quickly that their own understanding of God was thoroughly Scripture-based and learned, while the clerics resorted to empty chatter only: "wie haben sie doch mugen yhr hertz stillen und recht gutte Christen werden?" (315; how would they have been able to please their hearts and become good Christians?).

Luther strongly argued that it would be necessary to talk to Jews in a friendly manner and to instruct them properly based on the biblical text if one wanted to convince them to convert to Christianity (315). Arrogance and hubris would not achieve anything and should be condemned; and then Luther draws the interesting analogy to the Apostles who also had been Jews. If those had similarly engaged with the other people, "uns heyden" (315; us heathen), no one would have accepted the new faith. Instead, the Apostles' strategy had been predicated on brotherly love for the heathens. Consequently, the Christians at Luther's time ought to reach out to the Jews, whom he identifies as their brothers: "bruderlich mit den Juden handeln" (315; interact with the Jews in a brotherly fashion). In a short, often overlooked side remark, Luther alerts his readers that even the present Christians would have to struggle hard to achieve true faith and to accept Christ. In essence, "so sind wyr dennoch heyden" (315; we are still heathens). He recognizes Jews as descendants from Christ, while the Christians are their brothers-inlaw. In terms of blood relationship, the Jews would be even closer to Christ than the Christians, especially because God had selected the Jews from early on as the only recipients of the holy Scriptures (315). In a funny twist, Luther then addresses the Catholics and encourages them to label him not simply a heretic, but, more appropriately, a Jew (316).

In the subsequent section, the author investigates the relationship between the soul and the devil, revisits the history of Adam and Eve, and God's promise not to abandon His people (316-17). He also demonstrates, once again, that Christ was God's son and not a human, hence not descendant from flesh, or a material condition (318). Moreover, Luther then engages with the issue of Mary's virginity, which, according to St. Paul, was of no relevance for our understanding of Christ's nature. The notion of virginity pertains to a person's character and is not to be confused with biological virginity since "Eyn mutter kan nicht denn nur eyn weybs bilde seyn" (319; A mother can be nothing but a woman). Apparently, Luther brings up all those issues because they force him to engage with Jewish interpretations of the Old Testament as the anticipation of Christ's nativity (321). This also implies linguistic challenges as to the proper translation of Hebrew words for a virgin. Insofar as the Jews do not acknowledge the Gospels, Luther turns to the text by the prophet Isaiah and debates with his opponents in a purely intellectual fashion about the true meaning of important terms.

Luther mocks the Jews a little, observing their extreme insistence on a strict reading of every word for the Virgin Mary, when the real issue would be her virginity in her person: "jungfraw an der person" (322). Laughing about the ridiculous word pinching, he offers the compromise, in German, to call Mary a "magd" (322; maid), meaning that she was nubile but still young and honorable. For him, the term 'virgin' would be too amorphous and could apply to all kinds of women of different age (322-23), whereas virginity really implies a state of mind, that is, 
virtues and honorability. Luther's text thus demonstrates its character as a learned treatise dealing with etymology and the proper translation of the Hebrew word for 'virgin, but in that context it also reveals the extent to which the author was prepared and willing to engage with Jewish intellectuals about the correct method of rendering the Hebrew expression for a pregnant woman into German (323). The basic conflict or disagreement between Christians and Jews thus suddenly boils down to basic philological issues pertaining to the proper analysis of biblical comments on the Virgin Mary.

Subsequently, Luther returns to his initial concern and explores how he might be able to reach out to Jews and convince some of them to convert to Christianity, or at least to return back to the faith of their fathers (325). Moreover, as he underscores, "wollen wyr weytter mit yhn handeln und den ihenigen, szo mit yhn handeln wollen, eyn weyße und spruch fur legen, der sie gegen yhn gebrauchen sollen" (325; we want to continue to engage with them and with those who are willing to engage with them, and present them with statements and comments which they should use against them).

Luther's arguments against the Jews entirely remain on the level of a philological analysis of the biblical text according to which their own interpretation appears to be misleading. Luther subsequently enters into a narrow interpretation of Jewish history, such as the Babylonian Captivity (326). The critical question both for him and the Jews would be whether the Messiah has arrived already or is still to come, but both sides would agree that the promise itself amounts to a glorious projection of human destiny in the afterlife, but now already here on earth (326). Luther defends his belief in Christ as the promised Messiah, whereas the Jews reject this interpretation, which all amounts to the question of how to read certain biblical statements (327).

The Jews' historical perspective, as Luther reads it, is limited to a long series of kings who ruled and then passed away again, whereas the Christian teaching pertains to the last king, the Messiah, whose rule would be eternal and beyond all material limitations (328). The belief in the transformation from death to everlasting life, as in the case of Christ, would differentiate the Christian from the Jew, which Luther argues on the ground of the New Testament (328), which leaves, however, no room for his imaginary Jewish opponent: "Drumb mags niht eyn leiplich konigreich seyn ym sterblichen vergenglichen guttern und weßen" (328; Therefore it cannot be a physical kingdom determined by temporary goods and nature). Drawing the attention to the metaphorical expression in Scripture that people in the future would wash their clothes in wine and tie the ass to a wine stock, he asserts immediately that all this would not make much sense in reality, so the careful reader would be forced to translate this image and search for the deeper truth (329).

Undoubtedly, Luther does not want to grant any room to his Jewish counterpart and insists that Christ is the longpromised Messiah, and he urges his listeners to accept his own reading of the biblical text, which hence amounts to a philological argument, above all, although he also aims at offering a strong theological teaching: "Doch diße außlegung werden die Juden nicht achten, bis sie zuvor erbey komen und erkennen, das Christus komen seyn musse nach dißem spruch" (330; But the Jews will not acknowledge this interpretation until they will have changed their mind and recognized that Christ must have already come according to this statement). Luther tries his hardest to convince his listeners that the prophecy about the coming of Shilo (Genesis 49: 10-12) must be applied to the arrival of Christ, and this both in theological and practical historical terms (330).

Luther relentlessly insists that the entire historical development following the life of Christ would confirm His divine nature, and it would be impossible not to acknowledge Him as the long-prophesied Messiah (331). Nevertheless, he also recognizes that the debate about the true meaning of the promised rebuilding of Jerusalem has been ongoing, with no solution in sight, pitting Jews and Christians against each other. Luther himself is trying now to solve the problem, but it is an intellectual effort predicated on the assumption that rational arguments would work best in this case.

He obviously works very hard to gain the upper hand in this philological and theological exchange and is determined to develop a convincing case in order to convert the Jews. As to Gabriel's announcement of the Messiah, he concludes: "Das ist yhe, meyn ich, gewiß und klar gnug" (332; This is now, I believe, certain and clear enough). In other words, Luther engages in an intensive debate and trusts that his textual analysis will gain the upper hand. He believes that the Jews actually have already understood the same truth for a long time but continue to hang on to their old convictions and resort to "mutwillige ausfluchte on allen grund" (332; wilful prevarication without any foundation).

Luther even draws on historical reflections and makes a strong case for his own interpretation, sorting through the various arguments brought forth by the Jews, with whom he seems to have had multiple direct contacts, debating these specific points, as he outlines, over and over again (332-33). He relies on a rational approach, above all, and rejects the Jewish claims, convinced that his arguments are watertight: "Schliessen wyr und uberwinden der Juden 
yrthum mit gewallt, das der rechte Messiah komen sey nach dem widdergebawten hernach und fur dem tzustoreten Jerusalem" (333; We conclude and reject with full force the Jews' error, claiming that the true Messiah had come after the rebuilding of Jerusalem [by Nehemiah] and prior to its destruction [by Titus]). However, Luther himself realized how complicated this historical calculation might be, so he backtracks and explains further details, entering an extensive analysis of data and names in biblical times.

Most interestingly, Luther also reflects on Christ's crucifixion, but at first he does not associate His Passion with the Jews specifically (335), and only refers to some individuals "die yhn creutzigen und auß dißer wellt treyben" (335; who crucify and chase him away from this world). What matters for the author in this context is to compile exhaustive evidence to prove Christ's true nature as the Messiah. Only when Luther can adduce enough proof, does he hope to win the debate about the only valid faith: "Wyl denn schrifft und geschicht so geweltiglich mit eynander uber eyn treffen, haben ja die Juden nichts, das sie da widder mugen sagen" (335; Insofar as Scripture and history agree with each other so forcefully, the Jews have nothing to argue against it). In short, Luther makes every possible effort to convince the opponent with philological, theological, logical, and historical arguments and thus to prove that Christ must be acknowledged as the long-anticipated Messiah.

Only here, at the end of his treatise, does Luther resort to the traditional charge against the Jews, claiming that they had crucified Christ (336). But he also observes that the Jews are aware of their own shortcomings and their errors in the proper understanding of the biblical texts, especially the prophecies because they do not comprehend the metaphorical messages and do not figure out the historical specifics related in the Old Testament: "Den yhr verstorung fulen sie ja wol, die unmeßlich grosser ist denn sie noch yhe erlitten haben" (335-36; They certainly feel their destruction which is infinitely larger than what they have ever suffered). As hostile as this statement certainly sounds, it is based on Luther's conviction that he has successfully made rational points and can claim to be the winner in their debate. As a debater, however, like countless predecessors in the late Middle Ages, he heavily relied on the evidence of his own discourse and was convinced that his words would be powerful enough to reach out to the other side.

Luther feels completely certain that the Jews would be irritated about the Christians' claim that Jesus was both a human being and also the true God. However, he is also sure about his own ability to adduce more evidence based on Scripture to complete his rational endeavor to convert Jews to the Christian faith. Intriguingly, he admits at the same time that his own arguments so far might have been too harsh and difficult to achieve the desired effect on the Jews: "Aber es ist zum anfang tzu hart, laß sie tzuvor milch saugen und auffs erst dißen menschen Jhesum fur den rechten Messiah erkennen. Darnach sollen sie wyn trincken und auch lernen, wie er warhafftiger Gott sey" (336; For the beginning this is too difficult; let them first suckle milk and and recognize this man Jesus as the true Messiah. Thereupon they shall drink wine and learn that He is the true God).

Reaching out to the Jews, once again, Luther admits that they seem to have been misled for much too long a time with respect to the coming of the Messiah. It would be virtually impossible for Jews to accept that God could take on human shape, i.e., transform into Christ (336). Consequently, Luther requests from his Christian audience to take a soft approach and to work carefully with the Jews, teaching them the 'truth= on the basis of Scripture, "so mochten yhr ettliche herbey komen" (336; then a good number of them might join us).

He adamantly rejects the traditional strategy pursued by the Catholic clergy, attacking Jews for all kinds of wrongdoings and blaming them for many different faults. This would all be nothing but "narren werk[ ]" (336; foolishness). Treating them like dogs would not achieve anything, and forbidding them to live among the Christians, to carry out an ordinary profession, and denying them the right to participate in the larger community would only force them to turn to the practice of usury as the only way out of their misery. Full of aggravation, Luther exclaims: "wie sollt sie das bessern" (336; how can this improve them!). Certainly a deeply paternalistic attitude, but also one informed by a certain degree of sympathy (toleration!).

In order to reach out to Jews in a constructive manner would require not to follow the papal strategies, but to embrace them with "Christlicher liebe gesetz" (336; the law of Christian love). They should receive the legal rights to live within the Christian community and to pursue a regular job: "sie freuntlich annehmen" (336; accept them in a friendly manner). Once they would be around long enough, they would begin to understand and to appreciate the Christian teachings, and hence eventually to convert. Luther is fully prepared to recognize that some would never pursue that path and would stubbornly remain Jewish, especially because he knows fully well that many Christians do not live up to the basic religious standards of their Church either.

Although this treatise belongs to the shorter ones from Luther's quill, it consists of several very distinct parts and carries many different messages of great significance. At first he defends himself against various types of malignment, and then he turns to the question of how Christians should operate with Jews. This provides him with 
an opportunity to criticize the members of the Catholic clergy who treat Jews in a most abject, hateful, and derogatory manner. Luther, instead, insists, both at the beginning and at the end of the treatise, on the great need to communicate with them in a friendly fashion. But he does not assume a tolerant attitude, such as represented by Nathan in Lessing's play from 1779, and strongly endeavors to demonstrate that Christianity is the only true faith.

The central part of his treatise consists of historical, theological, and philological investigations, comparing and contrasting various types of interpretations of central scriptural passages. He claims, at the end, to have proven satisfactorily and exhaustively that the Christian teaching regarding Jesus as the true Messiah deserves full recognition. He laments, subsequently, that Jews have lived for too long in their self-imposed ignorance and misunderstanding of the true messages offered by Christ. However, and this constitutes the remarkable conclusion, Luther urges his readers to pursue an approach toward their Jewish neighbors which we would call toleration today. Aggressive confrontation, hostile opposition, and violent repression of Jews would not achieve anything and only harden the fronts between both sides. Instead, as Luther insists, anyone interested in reaching out to Jews and in trying to convert them would have to acknowledge them first as neighbors in their midst.

A friendly tone among both Christians and Jews would create the foundation for both sides to approach each other constructively. Undoubtedly, Luther acknowledged all such strategies as appropriate because he was firmly convinced that the Christian teachings were the only ones to be regarded as concerned spreading the religious truth. We would call this 'toleration' today, but not necessarily 'tolerance.'.

In his later life, Luther was to turn to radical anti-Judaism and hence to embrace an ugly form of intolerance, as we have seen above already. But this early treatise from 1523 presents to us a thinker who was willing to address the religious opponent, to include him/her in his own discourse, to acknowledge Jewish opinions, which he, however, subsequently discredited through a careful analysis of the social conditions for the members of that minority group. In this essay, at least, Luther strongly and explicitly advocated for open communication and friendly relations across the dividing lines between Christianity and Judaism.

His ultimate desire was to convince Jews that their own interpretation of the Old Testament was flawed and that the Christian teachings ought to be acknowledged and accepted. As scholars have observed, however, this was not to last very long, since Luther soon began to shed his early positions and to assume an increasingly hostile attitude, which we certainly would be justified to call anti-Judaic.

As long as we do not search for evidence that Luther might have been a tolerant thinker, then this and other tracts allow us to acknowledge a definite element of toleration in his early thinking. Unfortunately, this feature in the mindset of the young man Luther was not to last, and strongly anti-Judaic terms, images, phrases, prejudice, and even open xenophobia entered the picture in the subsequent years. Nevertheless, toleration, which clearly emerges in this early treatise, proved to be a remarkable phenomenon, especially for the early Protestant Reformation, as Heiko A. Oberman had indicated already in his seminal study from 1981/1984. (Note 25)

Luther defended, and how else could it be, his own faith as the only true one, and he resorted to all of his biblical, philological, theological, and historical knowledge and understanding. But he pursued his task to reach out to Jews and to convince them that the Christian teaching was right and the Jewish faith wrong by means of a rational, analytic discourse. He explicitly predicated this discourse on the assumption that only a friendly, cooperative, even tolerant attitude would achieve the desired effect. We know that in his later years he left all this far behind himself and turned into a rabid anti-Judaist, but the treatise Daß Jesus Christus ein geborner Jude sei speaks a very different language and deserves to be included in the religious discourse determined by toleration. (Note 26)

Without including explicit references, we can read this treatise as the Protestant continuation of an old discourse extending as far back as to the twelfth century. Peter Abelard (d. 1142) set the tone with his Dialgoue, and this was then followed by such late medieval intellectuals as Ramon Llull (1231-1316), Marsiglio of Padua (12751396), and Nicholas of Cusa (1401-1464). We would also have to consider treatises such as the Dialogus inter Iudaeum requirentem et Christianum respondentem by Petrus Damianus (1007-1072) or Annulus sive dialogus Christianum et Iudaeum by Rupert of Deutz (d. 1135), and each time we would discover the fundamental principle that the authors acknowledged their opponents' rational abilities to carry out a reasonable and logical debate over the religious differences. All those scholars and writers were driven by a strong intention to convince their opponents to convert to Christianity, but their efforts were systematically determined by their own willingness to acknowledge their "Verstandespotenzen" (potentiality to utilize one’s reason). (Note 27)

Tragically, as we might conclude, at least from our modern perspective, Luther, in his older age, abandoned this medieval and early modern tradition and also ignored the counter-development among the sixteenth-century Spiritualists and Anabaptists to focus on the own inner soul and to tolerate deviant approaches to God in order to establish a peaceful society (Sebastian Franck, Valentin Weigel, Sebastian Castellio). While the relevant research 
has already acknowledged the deep tensions between Luther's own binary positions, we should recognize, with all due respect, that the treatise from 1523 was predicated on the rational exchange with Jews and the possibility for both sides to reach an agreement regarding the proper reading of the biblical text (toleration). The philologist and logician in Luther still trumped the theologian, which was later no longer the case (intolerance), when he simply assumed that all Jews lied and could not be trusted within his own Christian universe. Previous research has amply demonstrated the true extent of Luther's hatred of the Jews (Note 14), but the key issue for us consists of the intriguing paradigm shift that occurred in his early life as a highly respected theologian. This thus sensitizes us to the problem all major religious leaders throughout world history might face and which might address also the countless contradictions in the fundamental Scriptural texts, whether the Bible, the Torah, or the Koran, where we find, just as our interests drive us, both statements of love and statements of hatred. If such an intellectual giant as Luther could change his opinion about the Jews so easily and so quickly, replacing his toleration with strong intolerance, it is easily conceivable that other major religious figures could also have gone through rapid transformations. The quest for true toleration, if not tolerance, thus proves to be very tenuous, as important as it will always be for humanity to survive.

The transformation, however, occurred rather quickly and can specifically be traced to Luther's personal meetings with a group of rabbis in 1525/1526 who had tried to establish a religious conversation with him. During the 1530s, Luther was confronted with numerous but spurious reports about successful Jewish missionizing in Moravia, and proved to be open to highly negative opinions by converted Jews about their former co-religionists, such as Johann Pfefferkorn (1469-1523). The willingness of the various princes to pursue openly anti-Judaic policies, such as the expulsion of Jews from Saxony in 1536, strengthened Luther's resolve no longer to engage with Jews in any tolerant fashion. (Note 28)

\section{Results}

Nevertheless, Luther's hostile stance and aggressive rejection of Jews later in his life do not undermine the value of his early writings (1523), in which he still allowed rational and interpretive strategies to dominate his entire approach to Judaism. Curiously, the early Luther can be viewed clearly in the tradition of Nicholas of Cusa, for instance, as meticulously examined by Cary J. Nederman, (Note 29) whereas the older Luther represents the much more repressive world of the sixteenth century. Human history does not necessarily 'progress' steadily toward better interhuman relations, and Luther himself was a dramatic case considering his almost shocking change of mind regarding Jews. However, reading Daß Jesus Christus ein geborner Jude sei within the context of Marsiglio of Padua's Defensor pacis, Ramon Llull's Book of the Gentile, Nicholas's De pace fidei, or Pico de la Mirandola's Oration On the Dignity of Man suddenly allows us to identify it as a significant contribution to the constant pursuit throughout the Middle Ages and the early modern age to identify 'moral' principles "capable of providing for 'peaceful coexistence and thus for 'basic human rights, to borrow Michael Walzer's terminology." (Note 30) While Luther's tract in its original German was printed nine times in 1523, and three times until 1525, it did not experience any further appeal and hence no additional separate reprinting, here disregarding the publication of Luther's collected works (1552, 1556, 1573, 1588, etc.). (Note 31) It might well be that the book market changed along with Luther and turned more anti-Judaic. However, in 1523, Luther still stood strongly in the tradition of the late medieval discourse on toleration and hoped that he could reach out to his Jewish contemporaries. Scholarship has already demonstrated clearly this shift in his thinking, but we should not throw the proverbial baby out with the bathwater and ignore that Luther was much more open-minded in early years than later. Not even the ideas of great men are simply written in stone, and Luther changed considerably in the course of time.

\section{References (select)}

Anselm, S. (2017). "Eine Frage der Freiheit: Das dialektische Erbe der Reformation," Ritter, Bauern, Lutheraner: Katalog zur Bayerischen Landesausstellung 2017 Veste Coburg und Kirche St. Moriz, 9. Mai bis 5. November 2017, Peter Wolf, Evamaria Brockhoff, et al. (Ed.). Darmstadt: Wissenschaftliche Buchgesellschaft, 22-28.

Beihefte (2017). Säkularisierungen in der Frühen Neuzeit: Methodische Probleme und empirische Fallstudien. Zeitschrift für Historische Forschung. Stuttgart: Steiner, 2017.

Christoph, N., \& Tobias, W. (Ed. 2017). Matthias Pohlig, "Eine Neuzeit ohne Reformation?” Eine andere deutsche Geschichte (1517-2017). Was wäre wenn.... Paderborn: Ferdinand Schöningh 2017, 20-36.

Classen, A. (2007). The Power of a Woman's Voice in Medieval and Early Modern Literature: New Approaches to German and European Women Writers and to Violence Against Women in Premodern Times. Fundamentals of Medieval and Early Modern Culture, 1. Berlin and New York: Walter de Gruyter, 2007. 
Dietrich, G., Roger, P., \& Udo, P. S. A. (ed. 2016). For more optimistic perspectives, see Reformation und Toleranz - Brücken über Jahrhunderte, 13. Bonn and Hermannstadt: Schiller Verlag, 2016.

Duncker, \& Humblot (2008). Säkularisierungen in der Frühen Neuzeit: Methodische Probleme und empirische Fallstudien. Zeitschrift für Historische Forschung, Beiheft, 41. Matthias, P. (Ed. 2015). Stuttgart: Franz Steiner Verlag, 2015.

Frankfurter Allgemeine Zeitung. (2017). Samuel Korn, "KRITIK AM REFORMATOR: Luthers Judenhass und die Pogrome." Retrieved Nov. 23, $2017 . \quad$ from http://www.faz.net/aktuell/politik/inland/luthers-judenhass-wird-zu-selten-thematisiert-15287981.html?print PagedArticle=true\#pageIndex_0

Merkel, A. (2017). "Ohne Religionsfreiheit nimmt die Gesellschaft Schaden.” Frankfurter Allgemeine Zeitung, Oct. 31, 2017. Retrieved from http://www.br.de/nachrichten/landesbischof-bedford-strohm-zum-reformationstag-100.html

Miriam, B. (2006). "A Jews in a Divided Christendom." A Companion to the Reformation World. R. Po-chia Hsia ed. Blackwell Companions to European History (Malden, MA, Oxford, and Carlton, Victoria, Australia: Blackwell, 2006), 471-85.

Susan, C. Karant-Nunn, (2007). "Reformation Society, Women and the Family." The Reformation World. Andrew, P. (Ed. 2000). (2000; London and New York: Routledge, 2002), 433-60. Thomas, E., \& Stephanie, A. (Ed. 2017). Luther, Kolumbus und die Folgen: Welt im Wandel 1500-1600. Nuremberg: Verlag des Germanischen Nationalmuseums.

\section{Notes}

Note 1. Luther, Kolumbus und die Folgen: Welt im Wandel 1500-1600, ed. Thomas Eser and Stephanie Armer (Nuremberg: Verlag des Germanischen Nationalmuseums, 2017).

Note 2. See the contributions to Säkularisierungen in der Frühen Neuzeit: Methodische Probleme und empirische Fallstudien. Zeitschrift für Historische Forschung, Beiheft, 41 (Berlin: Duncker \& Humblot, 2008); and to Reformation, ed. Matthias Pohlig (Stuttgart: Franz Steiner Verlag, 2015).

Note 3. Matthias Pohlig, "Eine Neuzeit ohne Reformation?," Eine andere deutsche Geschichte (1517-2017). Was wäre wenn..., ed. Christoph Nonn, Tobias Winnerling (Paderborn: Ferdinand Schöningh 2017), 20-36.

Note 4. Susan C. Karant-Nunn, "Reformation Society, Women and the Family," The Reformation World, ed. Andrew Pettegree (2000; London and New York: Routledge, 2002), 433-60; Albrecht Classen, The Power of a Woman's Voice in Medieval and Early Modern Literature: New Approaches to German and European Women Writers and to Violence Against Women in Premodern Times. Fundamentals of Medieval and Early Modern Culture, 1 (Berlin and New York: Walter de Gruyter, 2007).

Note 5. See now the contributions to Säkularisierungen in der Frühen Neuzeit: Methodische Probleme und empirische Fallstudien. Zeitschrift für Historische Forschung, Beihefte (Stuttgart: Steiner, 2017).

Note 6. For more optimistic perspectives, see Reformation und Toleranz - Brücken über Jahrhunderte, ed. Dietrich Galter, Roger Pârvu, and Udo Puschnig. Seria Academia, 13 (Bonn and Hermannstadt: Schiller Verlag, 2016).

Note 7. "Merkel: Ohne Religionsfreiheit nimmt die Gesellschaft Schaden," Frankfurter Allgemeine Zeitung, Oct. 31, 2017, online at: http://www.faz.net/aktuell/politik/inland/angela-merkel-spricht-beim-festakt-zum-reformationstag-15271558.ht $\mathrm{ml}$. See also http://www.br.de/nachrichten/landesbischof-bedford-strohm-zum-reformationstag-100.html.

Note 8. Samuel Korn, "KRITIK AM REFORMATOR: Luthers Judenhass und die Pogrome," Frankfurter Allgemeine Zeitung, Nov. 23, 2017; http://www.faz.net/aktuell/politik/inland/luthers-judenhass-wird-zu-selten-thematisiert-15287981.html?printPage dArticle=true\#pageIndex_0. For the great interest which the Nazis demonstrated in Luther's anti-Judaic treatises for their own propaganda, see Manfred Gailus, "Luthers 'Judenschriften= und ihre Rezeption im Protestantismus der NS-Zeit," Stiftung Topographie des Terrors: "Überall Luthers Worte...": Martin Luther im Nationalsozialismus. Catalogue of the eponymous exhibition (Berlin: Stiftung Topographie des Terrors; Gedenkstätte Deutscher Widerstand, 2017), 225-33. It seems dangerous to me, however, to draw conclusions about the way how the Nazis viewed Luther as indicative of Luther's own thoughts. 
Note 9. See, for instance, Richard Rex, The Making of Martin Luther (Princeton, NJ: Princeton University Press, 2017); Paul Dieterich, Mehr Licht als Schatten!: Martin Luther damals und heute. Blaubeurer geographische Hefte, 62 (Nürtingen: denkhaus Verlag, 2017); Detlev Brockes, Allein der Glaube: Martin Luther und der Reformationstag. 4th ed. (Kiel: Lutherische Verlagsgesellschaft, 2017); Hans Heinz, Endzeit und Endziel: Martin Luther und die Zukunft der Welt. Hoffnung Heute, 2 (Zürich: Advent-Verlag, 2017). Martin Luther im Widerstreit der Konfessionen: historische und theologische Perspektiven, ed. Christian Danz and Jan-Heiner Tück (Freiburg: Herder, 2017); Oxford Encyclopedia of Martin Luther, ed. Derek R. Nelson and Paul R. Hinlicky (New York: Oxford University Press, 2017); Lyndal Roper, Martin Luther: Renegade and Prophet (London: The Bodley Head, 2016). This list could be easily expanded; it is truly legion by now.

Note 10. For a good summary of the historical conditions for Jews and how they fared under the Protestant Reformation, see Miriam Bodian, "Jews in a Divided Christendom," A Companion to the Reformation World, ed. R. Po-chia Hsia. Blackwell Companions to European History (Malden, MA, Oxford, and Carlton, Victoria, Australia: Blackwell, 2006), 471-85.

Note 11. See now Anselm Schubert, "Eine Frage der Freiheit: Das dialektische Erbe der Reformation," Ritter, Bauern, Lutheraner: Katalog zur Bayerischen Landesausstellung 2017 Veste Coburg und Kirche St. Moriz, 9. Mai bis 5. November 2017, ed. Peter Wolf, Evamaria Brockhoff, et al. (Darmstadt: Wissenschaftliche Buchgesellschaft, 2017), 22-28.

Note 12. Peter von der Osten-Sacken, Martin Luther und die Juden: neu untersucht anhand von Anton Margarithas "Der gantz Jüdisch glaub" (1530/31) (Stuttgart: Kohlhammer, 2002); see also Thomas Kaufmann, "Die theologische Bewertung des Judentums im Protestantismus des späteren 16. Jahrhunderts (1530-1600)," Archiv für Reformationsgeschichte 91 (2000): 191-237. Kaufmann emphasizes, above all, that the Protestant societies since the 1530s had to come to terms with the Jewish population living in the cities.

Note 13. Winfried Frey and Andrea Frölich, Das Judenbild in den Flugschriften des 16. Jahrhunderts: Kontinuität und Wandel. CD-ROM, Johann Wolfgang Goethe-Universität Frankfurt a. M., 2008 (also: Nordhausen: Bautz, 2008).

Note 14. Martin Luther und die Juden: Luthers Judenschriften und ihre Rezeption: ein Projekt zum Reformationsjubiläum (Frankfurt a. M.: Gemeinschaftswerk der Evangelischen Publizistik, 2016); Dorothea Wendebourg, Die Reformation und die Juden: eine Orientierung (Wittenberg: Staatliche Geschäftsstelle Luther 2017). The topic, however, has already been addressed much earlier; see, for instance, Ernst Schäffer, Luther und die Juden. Christentum und Judentum: Serie 5: Geschichte der Judenmission, 2 (Gütersloh: Bertelsmann, 1917); Heinz Kremers, ed., Die Juden und Martin Luther - Martin Luther und die Juden: Geschichte, Wirkungsgeschichte, Herausforderung (Neukirchen-Vluyn: Neukirchener Verlag, 1985).

Note 15. D. Martin Luthers Werke: Kritische Gesammtausgabe, vol. 11 (Weimar: Hermann Böhlaus Nachfolger, 1900; rpt. Weimar: Verlag Hermann Böhlaus Nachfolger, 2003), 314-36. See also online at: http://www.glaubensstimme.de/doku.php?id=autoren:l:luther:d:luther-dass_jesus_jude. See also Luther's Works, vol. 45: The Christian in Society, vol. II, ed. Walther I. Brandt (Philadelphia: Muhlenberg Press, 1962), 199-229. See also online at: https://www.uni-due.de/collcart/es/sem/s6/txt09_1.htm. I have preferred, however, my own translations, though I have compared them with those in Brandt's volume. Despite many legitimate concerns with wikipedia, the relevant page is highly informative and detailed: https://de.wikipedia.org/wiki/Martin_Luther_und_die_Juden (all last accessed on Nov. 5, 2017).

Note 16. For a good summary, see Ekkehard Stegeman, "Judenschriften," Das Luther-Lexikon, ed. Volker Leppin and Gury Schneider-Ludorff (Regensburg: Verlag Bückle \& Böhm, 2014), 323-27.

Note 17. Most significant proves to be Thomas Kaufmann, Luthers "Judenschriften": Ein Beitrag zu ihrer historischen Kontextualisierung (Tübingen: Mohr Siebeck, 2011); Peter von der Osten-Sacken, Martin Luther und die Juden (see note 12). See also Die Juden und Martin Luther - Martin Luther und die Juden. Geschichte, Wirkungsgeschichte, Herausforderung, ed. Heinz Kremers et al. 2nd ed. (1985; Neukirchen-Vluyn: Neukirchener Verlag des Erziehungsvereins, 1987); C. Bernd Sucher, Luthers Stellung zu den Juden: Eine Interpretation aus germanistischer Sicht. Bibliotheca Humanistica \& Reformatorica, XXIII (Nieuwkoop: B. de Graaf, 1977); for a selection of relevant texts by Luther, with quick summaries and background information, see Walther Bienert, Martin Luther und die Juden: Ein Quellenbuch mit zeitgenössischen Illustrationen, mit Einführungen und Erläuterungen (Frankfurt a. M.: Evangelisches Verlagswerk, 1982). Cf. also Johannes Brosseder, Luthers Stellung zu den Juden im Spiegel seiner Interpreten: Interpretation und Rezeption von Luthers Schriften und Äußerungen zum Judentum im 19. und 20. Jahrhundert vor allem im deutschsprachigen Raum. Beiträge zur ökumenischen Theologie, 8 (Munich: Max Hueber, 1972). 
Note 18. Kuschel, Karl-Josef, "Jud, Christ und Muselmann vereinigt"? Lessings "Nathan der Weise (Düsseldorf: Patmos Verlag, 2004); Müller Nielaba, Daniel, Die Wendung zum Besseren: Zur Aufklärung der Toleranz in Gotthold Ephraim Lessings Nathan der Weise (Würzburg: Königshausen \& Neumann, 2000); Markus Pohlmeyer, Lessing, "Nathan" und die Toleranz: philosophisch-theologische Utopie in literarischer Gestalt!?; ... und weitere Essays, Fragmente und/oder Aufsätze; aus der Schule, für die Schule - und schon ein wenig jenseits davon. Didaktik, 10 (Berlin: LIT, 2007); H. B. Nisbet, Gotthold Ephraim Lessing: His Life, Works, and Thought (Oxford: Oxford University Press, 2008); Steven D. Martinson, Projects of Enlightenment: The Work of Gotthold Ephraim Lessing. Cultural, Intercultural, and Transcultural Perspectives. Hermeia. Grenzüberschreitende Studien zur Literatur- und Kulturwissenschaft, 11 (Heidelberg: Synchron, 2013). Again, there is a legion of studies addressing Lessing's famous play.

Note 19. Discourses of Tolerance and Intolerance in the European Enlightenment, ed. Hans Erich Bödeker, Clorinda Donato, and Peter Reill. UCLA Clark Memorial Library Series, 8 (Toronto: University of Toronto Press, 2009). Kelly James Clark, Abraham's Children: Liberty and Tolerance in an Age of Religious Conflict (New Haven, CT: Yale University Press, 2012); Forst, Rainer. Toleranz und Fortschritt. Sitzungsberichte der Wissenschaftlichen Gesellschaft an der Johann-Wolfgang-Goethe-Universität Frankfurt am Main, 52.2 (Stuttgart: Franz Steiner Verlag, 2015).

Note 20. Heiko A. Oberman, "Die Juden in Luthers Sicht," id., The Roots of Anti-Semitism in the Age of Renaissance and Reformation, trans. James I. Porter (1981; Philadelphia, PA: Fortress Press, 1984), 136-62; here 139-40.

Note 21. Kaufmann, Luthers “Judenschriften"(see note 17), 12.

Note 22. Ein Thema - zwei Perspektiven: Juden und Christen in Mittelalter und Frühneuzeit, ed. Eveline Brugger (Innsbruck: Studien-Verlag, 2007); Ashkenazi Jews in Early Modern Europe, ed. Predrag Bukovec (Mainz: Institut für Europäische Geschichte, 2012); Revealing the Secrets of the Jews: Johannes Pfefferkorn and Christian Writings about Jewish Life and Literature in Early Modern Europe, ed. Jonathan Adams and Cordelia Heß (Berlin and Boston: Walter de Gruyter, 2017).

Note 23. For a rather unusual, Jewish perspective toward Luther's anti-Judaic opinions, see Pinchas E. Lapide, "Stimmen jüdischer Zeitgenossen zu Martin Luther," Die Juden und Martin Luther (see note 11), 171-85. For concrete historical investigations of sixteenth-century Jews, see Rex Rexheuser, Juden im öffentlichen Raum einer christlichen Stadt : Posen im 16. -18. Jahrhundert. Deutsches Historisches Institut Warschau: Quellen und Studien, 33 (Wiesbaden: Harrassowitz Verlag, 2017); Juden und ländliche Gesellschaft in Europa zwischen Mittelalter und Früher Neuzeit (15.-17. Jahrhundert): Kontinuität und Krise, Inklusion und Exklusion in einer Zeit des Übergangs, ed. Sigrid Hirbodian and Torben Stretz. Forschungen zur Geschichte der Juden : Abteilung A, Abhandlungen, 24 (Wiesbaden: Harrassowitz Verlag, 2016); Albrecht Classen, "Complex Relations Between Jews and Christians in Late Medieval German and Other Literature," Jews in Medieval Christendom: “Slay them Not", ed. Kristine T. Utterback and Merrall Llewelyn Price (Leiden and Boston: Brill, 2013), 313-38; Ein Thema - zwei Perspektiven: Juden und Christen in Mittelalter und Frühneuzeit, ed. Eveline Brugger and Birgit Wiedl (Innsbruck, Vienna, and Bozen: Studien-Verlag, 2007); Renate Overdick, Die rechtliche und wirtschaftliche Stellung der Juden in Südwestdeutschland im 15. und 16. Jahrhundert: dargestellt an den Reichsstädten Konstanz und Eßlingen und an der Markgrafschaft Baden. Konstanzer Geschichts-und Rechtsquellen, 15 (Constance: Thorbecke, 1965). The literature on this topic is expansive, which by itself indicates the true extent to which Jewish life continued to flourish in many parts of Germany, specifically despite Luther's bitter diatribes against them.

Note 24. Hans-Martin Kirn, "Luther und die Juden," Handbuch Luther, ed. Albrecht Beutel (Tübingen: Mohr Siebeck, 2012), 217-24; here 219-20. This handbook is now available in its 2nd rev. and expanded ed. (2017). See also Ekkehard Stegeman, "Judenschriften" (see note 16).

Note 25. The most seminal study in this field continues to be Heiko Augustinus Oberman, The Roots of Anti-Semitism (see note 20). Cf. also Henry Kamen, Intoleranz und Toleranz zwischen Reformation und Aufklärung. Kindlers Universitätsbibliothek, 15 (Munich: Kindler, 1967). See also the recent contributions to Recounting Deviance: Forms and Practices of Presenting Divergent Behaviour in the Late Middle Ages and Early Modern Period, ed. Jörg Rogge. Mainz Historical Cultural Sciences (Bielefeld: transcript Verlag, 2016). Most recently, see Hein Retter, "Zur Frage der Toleranz in der Epoche zwischen Reformation und Aufklärung: On the Question of Tolerance in the Epoch between the Reformation and Enlightenment," International Dialogues on Education. Past and Present 4.2 (2017): 62-77. Nevertheless, we also can still draw on Karl Völker, Toleranz und Intoleranz: im Zeitalter der Reformation (1912; Grafrath: Boer, K, 2016). 
Note 26. Luther is not included, for instance, in the anthology Wege zur Toleranz: Geschichte einer europäischen Idee in Quellen, ed., intro., and explained by Heinrich Schmidinger (Darmstadt: Wissenschaftliche Buchgesellschaft, 2002).

Note 27. Norbert Winkler, “Toleranz im Mittelalter?” Deutsche Zeitschrift für Philosophie 8 (1991): 853-67; here 857. See also the contributions to Beyond the Persecuting Society: Religious Toleration Before the Enlightenment, ed. John Christian Laursen and Cary J. Nederman (1998; Philadelphia, PA: University of Pennsylvania Press, 2011). I have explored this larger corpus of theological and philosophical approaches to the question regarding toleration and tolerance in a new monograph, History of Tolerance and Toleration in the Middle Ages and Early Modernn Time (New York and London: Routledge, 2018). I do not, however, engage much with Luther there.

Note 28. Kirn, "Luther und die Juden" (see note 24), 220.

Note 29. Cary J. Nederman, Worlds of Difference: European Discourses of Toleration, c. 1100-c. 1550 (University Park, PA: The Pennsylvania State University Press, 2000). He mentions Luther once, but only in passing and in a different context. Nevertheless, Luther's treatise from 1523 would have well fit into the discourse as outlined by Nederman.

Note 30. Nederman, Worlds of Difference (see note 29), 118.

Note 31. D. Martin Luthers Werke, vol. 11 (see note 15), 308-10. I have also checked the VD16 online, with no additional data found. In fact, there only seven printings are listed.

\section{Copyrights}

Copyright for this article is retained by the author(s), with first publication rights granted to the journal.

This is an open-access article distributed under the terms and conditions of the Creative Commons Attribution license (http://creativecommons.org/licenses/by/4.0/). 